Correction

\title{
Correction: Pless, B. Risk Compensation: Revisited and Rebutted. Safety 2016, 2, 16
}

\section{Barry Pless}

Professor Emeritus, Pediatrics and Epidemiology, McGill University, 434 Lansdowne, Westmount, QC H3Y2V2, Canada; barry.pless@mcgill.ca; Tel.: +1-514-935-9264

Academic Editor: Jake Olivier

Received: 21 September 2016; Accepted: 21 September 2016; Published: 21 September 2016

I regret that the following errors have been found in the published paper [1]. Direct quotations attributed to [2] were not accurate and the text has been updated accordingly. I apologise to the journal editors, the readers of Safety and authors of [2] for any inconvenience.

\section{References}

1. Pless, B. Risk Compensation: Revisited and Rebutted. Safety 2016, 2, 16. [CrossRef]

2. Gamble, T.; Walker, I. Wearing a bicycle helmet can increase risk taking and sensation seeking in adults. Psychol. Sci. 2016, 27, 289-294. [CrossRef] [PubMed]

(C) 2016 by the author; licensee MDPI, Basel, Switzerland. This article is an open access article distributed under the terms and conditions of the Creative Commons Attribution (CC-BY) license (http://creativecommons.org/licenses/by/4.0/). 